\title{
FORUM
}

\section{Towards 'men who have sex with men- appropriate' health services in South Africa}

\author{
K B Rebe, ${ }^{1}$ MB ChB, FCP (SA), DTM\&H, Dip HIV Man (SA); G De Swardt, ${ }^{1}$ BA, MW; H Struthers, ${ }^{1}$ MBA \\ J A McIntyre, ${ }^{1,2} \mathrm{MB} \mathrm{ChB}, \mathrm{FRCOG}$ \\ ${ }^{1}$ Anova Health Institute, Johannesburg and Cape Town, South Africa \\ ${ }^{2}$ Centre for Infectious Diseases Epidemiology and Research, School of Public Health and Family Medicine, \\ University of Cape Town, South Africa
}

Corresponding author: KB Rebe (rebe@anovahealth.co.za)

\begin{abstract}
Health programming for men who have sex with men (MSM) in South Africa has been ignored or absent until fairly recently, despite this population being at high risk for HIV acquisition and transmission. Anova Health Institute, with support from the US President's Emergency Plan for AIDS Relief (PEPFAR)/United States Agency for International Development (USAID) and in collaboration with the South African National Department of Health, launched the first state sector MSM-targeted sexual health clinic in 2010. The clinic has been successful in attracting and retaining MSM in care, and lessons learned are described in this article. Components contributing to the creation of MSM-appropriate healthcare services are discussed.
\end{abstract}

S Afr J HIV Med 2013;14(2):52-57. DOI:10.7196/SAJHIVMED.841

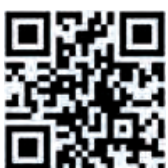

Until fairly recently, the healthcare needs of men who have sex with men (MSM) have been under-researched and under-resourced in South Africa (SA). ${ }^{[1]}$ This has occurred despite emerging local evidence confirming high rates of HIV among this key population. Notwithstanding inclusion in the country's previous National Strategic Plan for HIV and AIDS, STIs and TB (2007 - 2011), services for MSM were not scaled up nationally, although impressive strides have been made in some provinces such as the Western Cape and Gauteng. Evidence from modelling studies shows that in settings where concentrated HIV epidemics exist among key populations in countries with generalised heterosexual epidemics, failure to provide targeted and tailored HIV prevention and treatment programmes to key populations negatively affects HIV rates among the general population..$^{[2]}$

MSM in SA comprise of a diverse group of men who share only one behavioural commonality: they have sex with other men. ${ }^{[3]}$ Many MSM in SA do not identify with gay culture, which may be viewed as a Eurocentric cultural construct often considered foreign and 'un-African'.[4] The behaviour of MSM has, however, occurred across all cultures and all times, including in SA, and is therefore well described in African oral histories. Colonial oppressors were largely responsible for the criminalisation of sodomy on the continent. ${ }^{[5]}$ Homosexual activity in SA therefore often remains clandestine, with MSM identifying as heterosexual and dismissive of Westernised gay culture. ${ }^{[3]}$ This has implications for health messaging as nongay-identifying MSM are not targeted in either mainstream heterosexual or gay media platforms and remain invisible in healthcare settings.
For multi-factorial reasons, MSM are at particular risk for HIV acquisition and transmission. ${ }^{[6]}$ Biologically, unprotected receptive anal sexual intercourse is about 16 times more likely to transmit HIV than unprotected vaginal sexual intercourse. ${ }^{[7]}$ This is due to the friable nature of the rectal mucosa, which does not contain mucous-producing cells like the thicker, selflubricating lining of the vagina.

The vulnerability of MSM is further increased by structural factors such as a lack of funding for MSM-appropriate services, lack of specific skills training of health providers, and institutionalised stigma within the public healthcare sector. MSM patients generally avoid being identified as MSM, culminating in their elevated risk of HIV acquisition, transmission being overlooked, and a lack of counselling about the risks associated with unprotected anal sex. ${ }^{[8]}$

Organisations such as the Anova Health Institute, through it's innovative Health4Men project, and the Desmond Tutu HIV Foundation have been active in addressing these concerns in SA. In 2009 the Anova Health Institute, with support from the US President's Emergency Plan for AIDS Relief (PEPFAR)/ United States Agency for International Development (USAID), launched the first state sector clinic dedicated to MSM in the country. A further 6 sites have subsequently become operational across multiple provinces. Invaluable lessons have been learned through this process, which will undoubtedly serve as a template for the ongoing expansion of such services. ${ }^{[4,9-11]}$

MSM experience mainstream state sector healthcare services as unfriendly and prejudiced, which creates a barrier to accessing such services. ${ }^{[12]}$ Many local healthcare centres have become friendly to women at the exclusion of men. Women are a captive audience in these clinics, which 
they attend for antenatal care, childhood vaccinations, completion of children's roadto-health growth charts and other services. Clinics respond by improving their femalespecific skills and services. It is not unusual to find most of the educational materials in HIV clinics focusing on issues such as breastfeeding and female contraception, thereby alienating HIV-positive men. Other barriers to MSM healthcare access include fears about confidentiality related to their HIV status and sexual behaviour. The local catchment area of primary healthcare services is also often problematic; MSM who experience community-based stigma are unlikely to attend a clinic where they are known to other patients or staff members.

For a health provision site to be considered MSM-appropriate, a number of criteria need to be met. Firstly, most MSM require more than a friendly service (often incorrectly referred to as an MSM-sensitised service); they expect competence regarding their specific sexual healthcare needs. Services therefore need to be both sensitive and competent if they are to attract and retain MSM in care. ${ }^{[4]}$

The Ivan Toms Centre for Men's Health (ITCMH), a clinic of the Anova Health Institute in partnership with the Western Cape Department of Health (DoH) and funded by PEPFAR through USAID, was inaugurated in February 2010 in Cape Town. It has since provided care to over $3800 \mathrm{MSM}$. There are a few features which have contributed to the success of this clinic. There is buy-in and commitment by the provincial and National DoH. ${ }^{[13]}$ The service is marketed as a sexual health clinic for men. It is neither an HIV nor an antiretroviral therapy (ART) clinic, which means that patients in the waiting room cannot be identified as HIV-positive. Approximately half of the clients in the cohort are HIV-positive and half of those are receiving ART. Other MSM attend for HIV and sexually transmitted infection (STI) screening, syndromic STI management, counselling and other mental healthcare services, harmreduction services for MSM who use drugs, or for research and information purposes. This model assists in providing an enabling space that promotes feelings of anonymity regarding the reason for attendance, and allays fears of being identified as gay or HIV-infected when attending the clinic.

Clinic staff have received extensive sensitivity and competency training and are accepting of the diversity of MSM. They have become accustomed to providing service to MSM with either a feminine or masculine gender-identity, as well as to transgendered individuals. All staff are accustomed to referring to clients by their preferred name and pronoun (as opposed to their legal name).

\section{Table 1. Recommended service package for addressing the sexual health of MSM: HIV/AIDS}

\begin{tabular}{|c|c|c|}
\hline Primary & Primary care treatment (HIV/AIDS) & Opti \\
\hline $\begin{array}{l}\text { - HCT with MSM-appropriate counselling } \\
\text { yearly or more frequently if possible } \\
\text { exposures } \\
\text { - Condoms and water-based sexual lubricant } \\
\text { - Female condoms for anal sexual } \\
\text { intercourse } \\
\text { - Access to early ART if HIV-positive to } \\
\text { prevent transmission to sexual partners } \\
\text { ('treatment as prevention') } \\
\text { - Accessible PEP according to PEP protocols } \\
\text { - Targeted PrEP when available (local } \\
\text { guidelines available in a previous issue of } \\
\text { SAJHIVMED ) } \\
\text { - Counselling for behaviour change } \\
\text { - Reduce numbers of sexual partners } \\
\text { - Increase condom use, especially for the } \\
\text { highest risk sexual behaviours (e.g. anal } \\
\text { sex) } \\
\text { - Sero-sorting (choosing sexual partners on } \\
\text { the basis of HIV status) } \\
\text { - Sero-positioning (choosing to be receptive } \\
\text { in anal sex if HIV-positive and penetrative } \\
\text { if HIV-negative) } \\
\text { - Address alcohol, recreational drug and } \\
\text { tobacco use } \\
\text { freen and address mental health issues } \\
\text { frequently if high risk }\end{array}$ & $\begin{array}{l}\text { - CD4 } 4^{+} \text {count monitoring 6-monthly (point of } \\
\text { care or laboratory) } \\
\text { - Commence ART when: } \\
\text { - } \mathrm{CD} 4^{+} \leq 350 \text { cells/ } \mu \mathrm{l} \\
\text { - WHO stage IV } \\
\text { - Malignancies } \\
\text { (i.e. according to standard in-country } \\
\text { guidelines on when to initiate ART) } \\
\text { - Use ART according to local guidelines } \\
\text { - TDF/FTC/EFV fixed-dose combination } \\
\text { - AZT/3TC/Aluvia second-line } \\
\text { - Monitor for side-effects and efficacy according } \\
\text { to local guidelines } \\
\text { - CD4+ measurement } \\
\text { - VL at } 6 \text { and } 12 \text { months, then yearly } \\
\text { - FBC, if receiving AZT } \\
\text { - ALT, if receiving NVP } \\
\text { - Creatinine clearance at ART initiation and } \\
\text { yearly if receiving TDF } \\
\text { - Cholesterol, triglyceride and glucose } \\
\text { - Monitor adherence } \\
\text { - Self-reported } \\
\text { - Pill counts } \\
\text { - Pharmacy script refills } \\
\text { - Knowledge of ART drugs }\end{array}$ & $\begin{array}{l}\text { - } \mathrm{CD} 4^{+} \text {and VL monitoring } 3 \text { - 6-monthly } \\
\text { - Consider earlier ART initiation at high } \\
\text { CD } 4^{+} \text {count; patient will benefit directly and } \\
\text { there is less chance of HIV transmission to } \\
\text { sexual partners (i.e. less transmission within } \\
\text { the MSM community) ('ART as prevention') } \\
\text { - Consider early ART initiation for all } \\
\text { hepatitis B/C and HIV co-infections } \\
\text { - Expanded ART choice including ABC and } \\
\text { ritonavir-boosted ATV to improve regimen } \\
\text { tolerability if side-effects (also consider new } \\
\text { classes of ART) } \\
\text { - Extended monitoring } \\
\text { - CD4 }{ }^{+} \text {and VL } 3 \text { - 6-monthly } \\
\text { - Creatine clearance at } 1,3 \text { and } 6 \text { months } \\
\text { and then 6-monthly } \\
\text { - Cholesterol, triglyceride and glucose } \\
\text { - DEXA scan for osteopaenia if receiving } \\
\text { long-term TDF and other risk factors for } \\
\text { bone disease } \\
\text { - HLA typing if planning to use abacavir } \\
\text { - Extended adherence monitoring using } \\
\text { devices such as pill bottles which register } \\
\text { when they are opened } \\
\text { - Consider PrEP for HIV-negative MSM with } \\
\text { known high possible exposure rates to HIV } \\
\text { - Discordant couples } \\
\text { - Ongoing high-risk sexual behaviours } \\
\text { - Dommercial sex workers } \\
\text { Drug users }\end{array}$ \\
\hline \multicolumn{3}{|c|}{$\begin{array}{l}\text { MSM = men who have sex with men; } \mathrm{HCT}=\mathrm{HIV} \text { counselling and testing; } \mathrm{ART}=\text { antiretroviral therapy; } \mathrm{PEP}=\text { post-exposure prophylaxis; } \mathrm{PrEP}=\text { pre-exposure prophylaxis; } \mathrm{STI}=\text { sexually } \\
\text { transmitted infection; } \mathrm{WHO}=\text { World Health Organization; } \mathrm{SA}=\mathrm{South} \text { Africa; } \mathrm{TDF}=\text { tenofovir; } \mathrm{FTC}=\text { emtricitabine; } 3 \mathrm{TC}=\text { lamivudine; } \mathrm{EFV}=\text { efavirenz; } \mathrm{NVP}=\text { nevirapine; } \mathrm{AZT}=\mathrm{zidovudine} ; \\
\mathrm{VL}=\text { viral load; } \mathrm{FBC}=\text { full blood count; } \mathrm{ALT}=\text { alanine transaminase; } \mathrm{ABC}=\text { abacavir; } \mathrm{ATV}=\text { atazanavir; } \mathrm{HLA}=\text { human leukocyte antigen; } \mathrm{DEXA}=\text { dual energy X-ray absorptiometry. }\end{array}$} \\
\hline
\end{tabular}


Table 2. Recommended service package for addressing the sexual health of MSM: STIs

\begin{tabular}{|c|c|c|c|}
\hline Disease & Primary care prevention (STIs) & Primary care treatment (STIs) & Optimal specialised care \\
\hline Gonorrhoea & $\begin{array}{l}\text { - Regular screening for } \\
\text { symptoms } \\
\text { - Condoms and water-based } \\
\text { lubricant } \\
\text { - Risk-reduction counselling as } \\
\text { for HIV }\end{array}$ & $\begin{array}{l}\text { - Syndromic treatment according to } \\
\text { SA guidelines } \\
\text { - Partner(s) notification and } \\
\text { treatment } \\
\text { - Be aware that gonorrhoea can occur } \\
\text { in the urethra, pharynx or anus of } \\
\text { MSM } \\
\text { - Consider drug-resistant gonorrhoea } \\
\text { in cases of treatment failure }\end{array}$ & $\begin{array}{l}\text { - Confirm diagnosis with swab- and } \\
\text { laboratory-based testing, including NAATs } \\
\text { where available } \\
\text { - Treat confirmed cases as for primary care } \\
\text { - Consider screening for asymptomatic } \\
\text { disease at urethral and non-urethral sites }\end{array}$ \\
\hline Chlamydia & $\begin{array}{l}\text { - Regular screening for } \\
\text { symptoms } \\
\text { - Condoms and water-based } \\
\text { lubricant } \\
\text { - Risk-reduction counselling as } \\
\text { for HIV }\end{array}$ & $\begin{array}{l}\text { Syndromic treatment according to } \\
\text { SA guidelines } \\
\text { - Partner(s) notification and } \\
\text { treatment } \\
\text { - Be aware that chlamydial infections } \\
\text { occur in the urethra, pharynx or } \\
\text { anus of MSM }\end{array}$ & $\begin{array}{l}\text { - Confirm diagnosis with swab- and } \\
\text { laboratory-based testing, including NAATs } \\
\text { where available. } \\
\text { - Consider screening for asymptomatic } \\
\text { disease (most cases of anal chlamydial } \\
\text { infection will be asymptomatic) }\end{array}$ \\
\hline Syphilis & $\begin{array}{l}\text { - Regular assessment of risk } \\
\text { - Condoms and water-based } \\
\text { lubricant } \\
\text { - Risk-reduction counselling } \\
\text { about transmission }\end{array}$ & $\begin{array}{l}\text { - Confirm syphilis with laboratory- } \\
\text { based RPR and TPHA tests or rapid } \\
\text { point-of-care test } \\
\text { - Treat at point of care } \\
\text { - Partner(s) notification and } \\
\text { treatment }\end{array}$ & $\begin{array}{l}\text { - Treat as for primary care } \\
\text { - Consider lumbar puncture for HIV- } \\
\text { positive MSM with positive blood syphilis } \\
\text { serology and any neurological symptoms }\end{array}$ \\
\hline $\begin{array}{l}\text { Lympho- } \\
\text { granuloma } \\
\text { venereum }\end{array}$ & $\begin{array}{l}\text { - Risk assessment } \\
\text { - Regular screening for } \\
\text { symptoms } \\
\text { - Condoms and water-based } \\
\text { lubricant }\end{array}$ & $\begin{array}{l}\text { - Treat empirically if STI present } \\
\text { and prominent inguinal } \\
\text { lymphadenopathy } \\
\text { - Partner(s) notification and } \\
\text { treatment }\end{array}$ & - Confirm LGV serovar with NAATs \\
\hline $\begin{array}{l}\text { Human } \\
\text { papilloma } \\
\text { virus (warts) }\end{array}$ & $\begin{array}{l}\text { - Transfers easily and not totally } \\
\text { prevented by condom use, but } \\
\text { condoms still useful and partly } \\
\text { effective } \\
\text { - Most easily transferred by } \\
\text { contact with a visible skin wart, } \\
\text { but the virus may transfer even } \\
\text { without visible warts } \\
\text { - Advise to avoid direct contact } \\
\text { with visible warts } \\
\text { - Cover visible warts with a } \\
\text { plaster or condom } \\
\text { - Gardasil vaccination will } \\
\text { prevent some types of warts } \\
\text { and reduce the risk of HPV- } \\
\text { associated cancers (e.g. anal in } \\
\text { MSM), but is very expensive }\end{array}$ & $\begin{array}{l}\text { - Treat with topical preparations or } \\
\text { cryotherapy } \\
\text { - Partner(s) notification and } \\
\text { treatment } \\
\text { - Refer for surgical opinion if internal } \\
\text { or extensive disease } \\
\text { - Be aware that penile or anal warts } \\
\text { can lead to embarrassment and } \\
\text { pain, resulting in sexual dysfunction }\end{array}$ & $\begin{array}{l}\text { - Can use imiquimod ointment } \\
\text { preferentially (easier and convenient for } \\
\text { patient) } \\
\text { - Consider anal pap smear for MSM, } \\
\text { especially if prior anal warts } \\
\text { - Coagulase laser therapy to anal intra- } \\
\text { epithelial neoplastic lesions (similar to } \\
\text { cervical intra-epithelial neoplasia in } \\
\text { women) } \\
\text { - Biopsy any suspicious looking lesions } \\
\text { and send for histological evaluation } \\
\text { (MSM have a higher risk of anal cancers } \\
\text { compared with heterosexual men) } \\
\text { - Vaccinate with Gardasil (ideal to vaccinate } \\
\text { before onset of sexual debut); might } \\
\text { prevent warts and decrease risk of cancers; } \\
\text { may also decrease size of existing HPV } \\
\text { lesions }\end{array}$ \\
\hline Hepatitis A & $\begin{array}{l}\text { - Counselling about } \\
\text { transmission (faecal-oral) } \\
\text { - Risk assessment } \\
\text { - Check hepatitis A IgG } \\
\text { antibodies } \\
\text { - Previous hepatitis A confers } \\
\text { longstanding immunity } \\
\text { - Vaccinate if susceptible } \\
\text { - Contact trace for } \\
\text { immunoglobulin and } \\
\text { vaccination of known contacts }\end{array}$ & $\begin{array}{l}\text { - Supportive treatment of acute } \\
\text { hepatitis A } \\
\text { - Refer to specialist if clinically unwell } \\
\text { - Monitor liver function tests and } \\
\text { limit physical activity until settled }\end{array}$ & $\begin{array}{l}\text { - Hepatitis A is potentially serious } \\
\text { if contracted in adulthood; a small } \\
\text { percentage of patients develop severe } \\
\text { liver dysfunction and even failure, and } \\
\text { consequently require intensive support } \\
\text { - Most cases recover with no permanent } \\
\text { sequelae as hepatitis A does not have a } \\
\text { chronic phase }\end{array}$ \\
\hline
\end{tabular}

continued ... 
Table 2 (continued). Recommended service package for addressing the sexual health of MSM: STIs

\begin{tabular}{|c|c|c|c|}
\hline Disease & Primary care prevention (STIs) & Primary care treatment (STIs) & Optimal specialised care \\
\hline Hepatitis B & $\begin{array}{l}\text { - Counselling about } \\
\text { transmission } \\
\text { - Risk assessment } \\
\text { - Screen all MSM for hepatitis B } \\
\text { surface antibodies } \\
\text { - Vaccinate if susceptible } \\
\text { - Contact trace for } \\
\text { immunoglobulin and } \\
\text { vaccination of known contacts } \\
\text { - Screen MSM for prior hepatitis } \\
\text { B infection using hepatitis B } \\
\text { surface antigen } \\
\text { - Vaccinate all regular hepatitis } \\
\text { B-negative sexual partners } \\
\text { of MSM known with chronic } \\
\text { hepatitis B infections }\end{array}$ & $\begin{array}{l}\text { - Acute hepatitis B requires } \\
\text { supportive treatment } \\
\text { - Refer if clinically unwell } \\
\text { (encephalopathic, extreme nausea, } \\
\text { hypoglycaemia, sepsis, etc.) } \\
\text { - If hepatitis B and HIV co-infected, } \\
\text { initiate TDF-based ART early } \\
\text { to prevent disease progression. } \\
\text { TDF/3TC should then never be } \\
\text { stopped, even if alternative HIV } \\
\text { drugs are required in a second-line } \\
\text { or salvage regimen } \\
\text { - Hepatitis B may be curable with } \\
\text { interferon therapy, but this is very } \\
\text { expensive with limited access }\end{array}$ & $\begin{array}{l}\text { - Supportive therapy during acute disease } \\
\text { - Perform liver function tests, hepatitis B } \\
\text { E-antigen and hepatitis B viral load (these } \\
\text { parameters assist hepatologists to decide } \\
\text { who may benefit most from interferon and } \\
\text { related therapy) }\end{array}$ \\
\hline Hepatitis C & $\begin{array}{l}\text { - Counselling about } \\
\text { transmission } \\
\text { - Screen HIV-positive MSM who } \\
\text { use crystal methamphetamine } \\
\text { - Harm-reduction programmes } \\
\text { for drug users (e.g. needle } \\
\text { exchange), condoms and water- } \\
\text { based lubricant for anal sex } \\
\text { - There is no vaccine available; } \\
\text { only prevention is to avoid } \\
\text { exposure }\end{array}$ & $\begin{array}{l}\text { - Acute hepatitis C requires } \\
\text { supportive management } \\
\text { - Refer if clinically unwell } \\
\text { (encephalopathic, extreme nausea, } \\
\text { hypoglycaemia, sepsis, etc) } \\
\text { - Antiretroviral medications such } \\
\text { as TDF/3TC are inactive against } \\
\text { hepatitis C, but co-infected patients } \\
\text { should have their HIV treated early } \\
\text { at high CD } 4^{+} \text {counts }\end{array}$ & $\begin{array}{l}\text { - Perform liver function tests, hepatitis C } \\
\text { viral load and genotyping } \\
\text { - Refer to hepatologist for assessment for } \\
\text { interferon therapy (lower cure rates than } \\
\text { for hepatitis B) } \\
\text { - Assess and manage mental health } \\
\text { in patients taking interferon (causes } \\
\text { potentially severe depression) }\end{array}$ \\
\hline
\end{tabular}

Table 3. Examples of interventions for preventing HIV among MSM*

\begin{tabular}{|c|c|}
\hline Psychosocial & Biomedical \\
\hline Reducing number of sex partners & Increased HCT and early detection of positives \\
\hline Reducing alcohol and recreational drug use & Male and female condoms \\
\hline Increasing condom use for risky sexual behaviours & Condom-compatible sexual lubricant \\
\hline Increasing the use of condom-compatible lubricant & Early ART \\
\hline Sero-sorting & PEP \\
\hline Sero-positioning & STI screening and treatment \\
\hline Motivational counselling & PrEP (refer to SA guidelines) \\
\hline Couples' services including targeted counselling & Microbicides (undergoing research) \\
\hline $\begin{array}{l}\text { Combating societal homoprejudice and increasing access to } \\
\text { non-judgemental healthcare services }\end{array}$ & HIV vaccines (undergoing research) \\
\hline $\begin{array}{l}\text { Screening and management of depression and other mental } \\
\text { health disorders }\end{array}$ & $\begin{array}{l}\text { Harm-reduction programmes for drug users includes safe injection } \\
\text { technique, clean injecting equipment (needles), treatment of soft-tissue } \\
\text { abscesses, IEC materials, education about overdoses and linkage to } \\
\text { rehabilitation programmes for those who want to stop drug use }\end{array}$ \\
\hline $\begin{array}{l}\text { Development and dissemination of appropriate healthcare and } \\
\text { risk-reduction messages that address the specific sexual health } \\
\text { needs of MSM }\end{array}$ & $\begin{array}{l}\text { Medical male circumcision; does not provide the same risk reduction } \\
\text { as for heterosexual men but might protect bisexual men and those who } \\
\text { exclusively adopt the penetrative role in anal sex }\end{array}$ \\
\hline
\end{tabular}




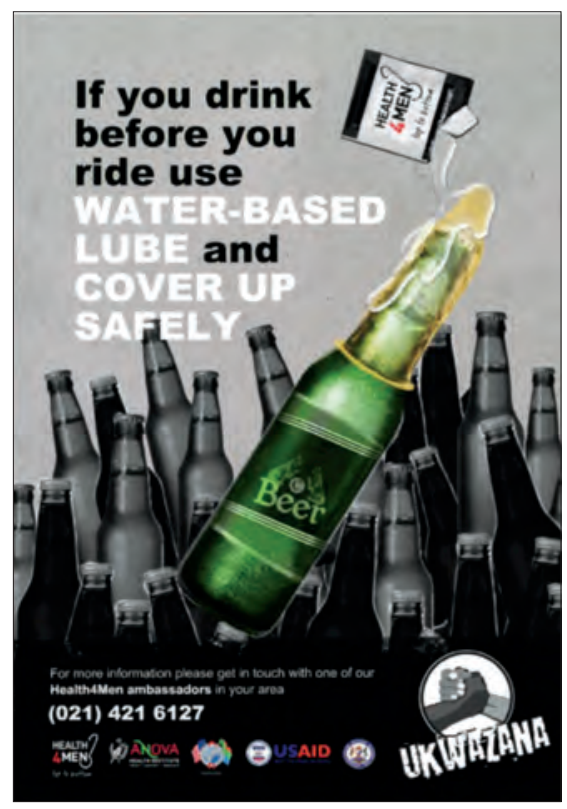

Fig. 1. The Ukwazana (getting to know each other) campaign. An example of HIV riskreduction messaging designed to reach MSM though township taverns/shebeens where MSM congregate.

The scope of practice encompasses holistic sexual health, including STI and HIV prevention, diagnostic and treatment services, as well as in-house access to mental healthcare services provided by staff who have specific experience in providing such care to MSM. Staff have been intensely trained in the specific features of sexual health pertaining to MSM. Medical staff have an expert understanding of how STI presentations, diagnosis and management plans differ in MSM, compared with heterosexual men. A good example is training in physical examination to detect and diagnose anal and pharyngeal presentations of STIs.

A package of care has been developed for the clinic and a clinical manual is available for guidance both in print format and online (http://www.anovahealth.co.za). ${ }^{[4]}$ It is understood that clinics may not be able to provide an optimal level of MSM healthcare due to resource constraints; therefore, a package of minimal and optimal services has been developed (see Tables 1 - 3).

Some specific features of the ITCMH that have worked well include the provision of MSM-sensitive HIV screening. Counsellors are trained to ask about male and female partners, to identify specific sexual behaviours and their risks (e.g. receptive unprotected anal intercourse), and to avoid adopting a hetero-normative attitude to counselling (such

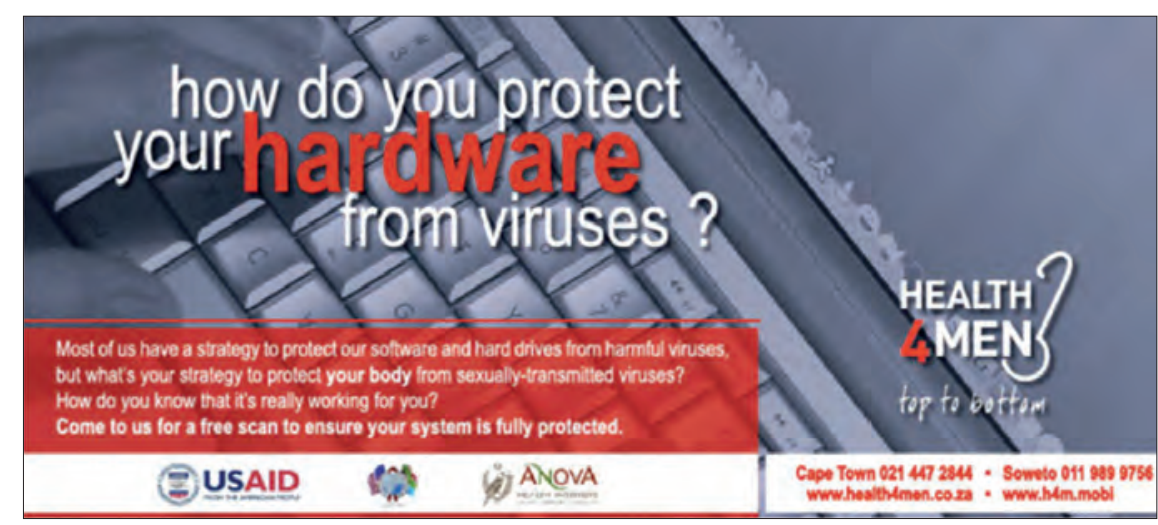

Fig. 2. An example of HIV risk-reduction messaging designed to reach gay-identified MSM through gaytargeted publications (the pink press).

\section{MSM resources}

South African MSM resources

- Anova Health Institute: http://www.anovahealth.co.za | Tel: +27 (0)11 7155800

- Health4Men: http://www.health4men.co.za | Tel: +27 (0)21 4216127

- The Ivan Toms Centre for Men's Health | Tel: +27 (0) 214472887

- Health4men Yeoville: email: yeoville@ahovahealth.co.za| Tel: +27 (0)72 6540816

- Health4Men Connect: http://h4M/mobi

(MSM-specific information via cellular phone technology)

- Other Health4Men sites or services: email: info@health4men.co.za| Tel: +27 (0)21 4216127

- Durban Lesbian and Gay Community Centre: email: info@gaycentre.org.za |

Tel: $+27(0) 313012145$

- Gay and Lesbian Network (Pietermaritzburg): email: info@gaylesbiankzn.org | Tel: +27(0) 333426165

- OUT LGBTI Well Being (Pretoria): email: administrator@out.org.za| Tel: +27(0)12 3445108

- The Desmond Tutu HIV Centre: http://www.desmondtutuhivcentre.org.za | Tel: +27(0)21 6506966

- Triangle Project (Cape Town): email: info@triangle.org.za | Tel: +27(0)21 6861475

International website resources for MSM health

- The Body: http://www.thebody.com

- Gay Men Fighting AIDS: http://www.gmfa.org.za

- The Global Forum on MSM and HIV (MSMGF): http://www.msmgf.org

- International Rectal Microbicides Advocates: http://www.rectalmicrobicides.org

as asking an MSM couple which is the man and which is the women in a relationship). MSM are also encouraged to screen for HIV together with their partners. ${ }^{[14]}$

Since MSM are at an elevated risk of acquiring and transmitting HIV, prevention technologies assume particular importance. Condoms, although generally available via the state, are mainly marketed through heterosexually-targeted campaigns that do not address the risks of unprotected anal sex. Condom-compatible lubricant required for comfortable anal sex is largely unavailable. Medical male circumcision is likely to fail to protect MSM to the same degree as heterosexual men, which leaves a deficit of effective prevention interventions. ${ }^{[15]}$ Available HIV-prevention resources that are evidence- based - such as condoms, lubricants, post- and pre-exposure prophylaxis (PEP and PrEP), and early treatment for positive MSM - should be prominent at all MSM-targeted sites.

Marketing MSM-appropriate services is challenging, especially in areas where MSM do not disclose their sexual behaviours and remain hidden to the healthcare system. It has taken time for MSM groups to develop trust in the clinic and the most effective marketing has occurred by word of mouth via clients who have had a positive health-affirming experience at the clinic. Health4Men employs peer educators, and key individuals in MSM communities from specific geographical areas have been recruited as ambassadors for the programme. Marketing and information, education and communication (IEC) materials 
have been developed through testing with MSM focus groups to ensure that the language is locally understood and contextually correct. Health information, referral links and interactive questions and answers are also available from the Health4Men's mHealth programme 'Health4men Connect' (h4m. mobi) and the programme's website.

The ITCMH was followed by the launch of the Simon Nkoli Centre For Men's Health in Soweto and, more recently, the Khayelitsha Male Clinic (Cape Town), the Zola and Chiawelo clinics (both in Soweto) and the Yeoville clinic (central Johannesburg). These sites have built on the evidence and experience gained from providing services at the ITCMH. Guidelines for the management of common MSM health problems have been developed and packaged into an intensive training package, which can be delivered at healthcare facility level to improve staff attitudes and skills and better allow for the provision of non-judgemental, appropriate MSM-targeted healthcare. Over time, once enough state clinics have received such training, it is hoped that MSM-specific healthcare services can be mainstreamed in standard HIV/ART/STI clinics. Many resources have been developed locally and abroad to assist healthcare providers in caring for their MSM clients in a compassionate and competent manner, even in instances where the beliefs of healthcare workers do not usually encompass an understanding of diverse male sexual identities and behaviours.

\section{References}

1. Rispel LC, Metcalf CA. Breaking the silence: South African HIV policies and the needs of men who have sex with men. Reprod Health Matters 2009;17(33):133-142. [http://dx.doi.org/10.1016/ S0968-8080(09)33442-4]

2. Beyrer C, Wirtz AL, Walker D, Johns B, Sifakis F, Baral S. The Global HIV Epidemics among Men Who Have Sex with Men. Washington DC: The International Bank for Reconstruction and Development/The World Bank, 2011. http://siteresources.worldbank.org/ INTHIVAIDS/Resources/375798-1103037153392/ MSMReport.pdf (accessed 22 April 2013).

3. Lane T, Mogale T, Struthers H, McIntyre J, Kegeles SM. "They see you as a different thing": The experiences of men who have sex with men with healthcare workers in South African township communities. Sex Transmit Infect 2008;84:430-433. [http://dx.doi.org/10.1136/ sti.2008.031567]

4. De Swardt G, Rebe K. From top to bottom: A sexpositive approach for men who have sex with men - a manual for healthcare providers. Johannesburg: ANOVA Health Institute, 2010. http://www. anovahealth.co.za/resources/entry/toptobottom/ (accessed 22 Apr 2013)

5. Delius P, Glaser C. Sex, disease and stigma in South Africa; historical perspectives. African Journal of AIDS Research 2005;4:29-36.

6. Baral S, Sifakis F, Cleghorn F, Beyrer C. Elevated risk for HIV infection among men who have sex with men in low- and middle-income countries 2000 - 2006. PLOS Medicine 2007;4(12):1901-1911. [http://dx.doi. org/10.1371/journal.pmed.0040339]

7. Baggaley R, White R, Boily M. HIV transmission risk through anal intercourse, systematic review, metaanalysis and implications for HIV prevention. Int
J Epidemiol 2010;39(4):1048-1063. [http://dx.doi. org/10.1093/ije/dyq057]

8. Carceres CF, Konda K, Segura ER, Lyerla R Epidemiology of male same-sex behaviour and associated sexual health indicators in low- and middleincome countries: 2003 - 2007 estimates. Sex Transmit Infect 2008;84:i49-i56. [http://dx.doi.org/10.1136/ sti.2008.030569.]

9. Rebe KB, De Swardt G, Pienaar D, Struthers H McIntyre J, eds. An African Clinic Providing Targeted Healthcare to Men-who-have-sex-with-men. 18th International Aids Conference, July 2010, Vienna. http://pag.aids2010.org/Abstracts.aspx?AID =5583 (accessed 22 April 2013)

10. Rebe KB, Struthers H, De Swardt G, McIntyre JA. HIV Prevention and treatment for South African men who have sex with men. S Afr Med J 2011;101(10):708-710.

11. De Swardt G, Rebe K, eds. MSM In Your Pocket. 1st ed. Johannesburg: Anova Health Institute, 2010. http:// www.anovahealth.co.za/resources/entry/msm_in_ your_pocket/ (accessed 22 April 2013).

12. Parry C, Peterson P, Dewing S, et al. Rapid assessment of drug-related HIV risk among men who have sex with men in three South African cities. Drug Alcoho Depend 2008;1(95):45-53. [http://dx.doi.org/10.1016/j. drugalcdep.2007.12.005

13. South African National AIDS Council (SANAC) National Strategic Plan on HIV, STIs and TB: 2012 2016. Pretoria: SANAC, 2012. http://www.doh.gov.za/ docs/stratdocs/2012/NSPfull.pdf (accessed 22 April 2013).

14. Stephenson R, Sullivan P, Salazar LF, Gratzer B, Allen S, Seelback E. Attitudes towards couples-based HIV testing among MSM in three US cities. Aids Behavior 2011;15:S80-S87. [http://dx.doi.org/10.1007/s10461011-9893-2]

15. Lane T, Raymond HF, Dladla S, et al., eds. Lower risk of HIV infection among circumcised MSM: Results from the Soweto Men's Study. 5th International Aids Society Conference on HIV Pathogenesis, Treatment and Prevention, Cape Town, 2009. http://www.ias2009.org/ pag/Abstracts.aspx?AID=2185 (accessed 22 April 2013). 